War. Under Sir Edward Appleton's able guidance, Britain has established a lead in the scientific applications of radio, which the country will look to the new Radio Research Establishment to improve. With the present team under Dr. Smith-Rose, and with Sir Edward at the head of the Department, they are not likely to be disappointed.

Deputy Scientific Adviser to Army Council : Prof. F. J. M. Stratton, O.B.E., F.R.S.

THE appointment of Prof. F. J. M. Stratton to the post of deputy scientific adviser to the Army Council has been announced. Prof. Stratton's retirement from the chair of astrophysics at Cambridge last October was announced in Nature (159, 463; 1947), and the record of his scientific work was noted. His was a retirement dictated by the rules of superannuation, and not by any loss of activity; so that his choice for and acceptance of this further post will be no more a surprise to his friends than his own preference for further service to merited retirement. The War Office is fortunate in securing the services of so able a man of science, particularly one who has given proof, through ten years service in the Army in two wars and a long association with the Cambridge O.T.C. and the Territorial Army, of his aptitude and interest in military affairs. While his appointment will be a temporary one for a limited period, the acquisition to the Scientific Civil Service, even for a short time, of such men as Prof. Stratton will be a source of strength to the Service, and the experience and leadership he can give to some of the younger men of science employed by the Army, in operational research and other tasks, will obviously be of the greatest value to them.

\section{Willard Gibbs Medal : Prof. Carl F. Cori}

Prof. Carl F. CoRr, professor of biochemistry in the Washington University School of Medicine, has been awarded the 1948 Willard Gibbs Medal of the Chicago Section of the American Chemical Society. This medal, one of America's highest scientific honours, goes to Dr. Cori for his achievements in research on the processes by which the body converts sugar into energy. $\mathrm{He}$ has been a leading worker in the difficult field of biological earbohydrate trans. formations for many years. His contributions have been of widespread importance involving adrenal, cortical, pituitary, and pancreatic roles in carbohydrate utilization as well as carbohydrate metabolism in tumours. A recent outstanding contribution is at least a partial solution of the problem of how insulin functions. He and his wife, Dr. Gerty T. Cori, who is also a professor of biochemistry in Washington University, received the Nobel Prize for Medicine for 1947 (see Nature, 160, 599; 1947) for determining the process by which the body stores sugar in the liver as glycogen, or animal starch, and then reconverts the glycogen to sugar as it is needed.

\section{Library of the Royal Society: Mr. H. W. Robinson}

ON March 31 Mr. H. W. Robinson retires from the office of librarian of the Royal Society. He joined the staff of the Society in 1902, when as a boy of fourteen he assisted both the chief clerk and the librarian. His work soon became exclusively associated with the Society's Library ; in 1930 he was raised from assistant to the post of assistant librarian and five years later to the position which he now holds. This forty-six years service to the Society has been twice broken by war. In the First World War Mr. Robinson served in the army with distinction; in the Second World War there was a period of service on the Central Register, which came between the strenuous work which he performed in seeing the Society's manuscripts and early printed books safely to Wales and his recall to the Society's service in 1943. Since then he has had the exacting but pleasant task of seeing the Library's books brought back from Oxford, where they had been stored by the Bodleian Library, and arranged in their places with a minimum of inconvenience and disturbance.

Mr. Robinson has a unique knowledge of the Society's Library and in particular of its extensive and priceless archives, a knowledge which he has always been delighted to put at the disposal of the scholars, from many countries, to whom his learning is well known. His intimate acquaintance with the Society's traditions and records has found expression in his services to the history of science. He is, for example, an authority on Robert Hooke, having edited, in conjunction with Mr. Walter Adams, the Diary in the possession of the Guildhall Library and having identified as another Diary of Robert Hooke the manuscript in the British Museum previously attributed to James Petiver. With Prof. Harcourt Brown and Dr. D. McKie he founded the Annals of Science, and he was actively associated with the foundation of the British Society for the History of Science, of which he is honorary treasurer. He has an intimate knowledge of many aspects of the bibliography of Isaac Newton, in particular of his manuscripts, and it has been arranged that after his retirement his services shall still be available to the Society, to assist Prof. H. W. Turnbull in editing the Newton letters. It is to be hoped that for many years to come Mr. Robinson's familiar figure will be seen about the Royal Society Library, working among the manuscripts that he loves so well.

\section{Reports on German War-time Industry and Science}

REPORTS of war-time scientific and industrial activities in Germany have been available to interested parties for some time. These reports were prepared by B.I.O.S. (British Intelligence Objectives SubCommittee), its American counterpart, F.I.A.T. (Field Information Agency, Technical), and the combined Anglo-American Agency, C.I.O.S. (Combined Intelligence Objectives Sub-Committee) which preceded them. Actual investigations in Germany ceased at the end of June 1947. To date, 2,720 reports have been issued. It is stated that more than one million copies have been sold or distributed to the universities, learned societies, trade and research associations and principal public libraries of Britain. The Board of Trade has now arranged for experts in each of the major fields to prepare critical summaries suitable for publication. These reports will be known as "B.I.O.S. Overall Reports" and there will be fifty of them, all of which are expected to be printed by the end of June. The first, on the petroleum and synthetic oil industry of Germany, has been pub. lished; the next six reports will be on shipbuilding and marine engineering, the German timber industry, the glass industry, the German road system, agriculture, and the rubber industry. All inquiries about these reports should be addressed directly to the Board of Trade, T.I.D.U., Research Section, 40 Cadogan Square, London, S.W.1. 
The Foreign Office announces the publication and distribution of the first volumes of the "FIAT Review of German Science", compiled by German experts under the direction of the British, American and French Field Intelligence Agencies (Technical). The Review is written in German and covers fundamental research in pure science during the years 1939-46. By agreement between the British, American and. French agencies, the first printing is a restricted edition for official distribution between the three Allies and U.N.E.S.C.O. The British share of about 250 sets will be issued to Government and other bodies within the Commonwealth, to universities and medical schools and to the libraries of certain learned and professional societies. It is hoped that the edition will be completed within the next six months. The Allied edition of the FIAT Review will be followed by a German edition. The latter, also printed in German, will be published by Dieterich'sche Verlagsbuchhandlung, Wiesbaden, Germany, and will be obtainable through normal trade channels. It is understood that volumes will not be sold separately but only in sets comprising the titles under the headings physics, chemistry, mathematics, medicine, biology and sciences of the earth.

\section{Eclipse Observations for Geodesy}

IT is now possible to amplify the brief reference in Nature of February 7 (p. 196) to the application to geodesy of the times of contact to be observed at different stations on the track of the annular eclipse of May 8-9, 1948. The first suggestion that such observations might provide information as to the earth's shape over areas where geodetic triangulation is impracticable was made by Mr. G. E. Barton (Mon. Not. Roy. Ast. Soc., 64, 105; 1926). His observations at Benkoelen at the eclipse of January 14, 1926, were spoilt by an unfortunate accident, but the idea was afterwards adopted, and expeditions from a number of countries used improved methods of time determination of such observations at the total eclipses of 1945 and 1947 by parties well separated in longitude. For the annular eclipse of next May, the National Geographic Society of the United States has prepared an elaborate scheme of observations at seven ground stations from Mergui in southern Burma to Kiska in the Aleutians. These will be supplemented by observations from aeroplanes of the U.S. Air Force; photographs of the eclipse will be taken from above the clouds from positions determ. ined by short-range radar navigational methods.

The U.S. Army's Map Service, Engineer and Signal Corps, the U.S. Navy, Air Force, Bureau of Standards, Coast and Geodetic Survey and State Department will co-operate with the National Geographic Society in the scheme. The leaders of the different parties are to be as follows : at Mergin, Mr. E. A. Halbach; at Bangkok, Prof. Charles H. Smiley with Prof. C. W. Miller; at Wu-K'ang, China, Father Francis J. Heyden with Dr. V. C. Chang; at Cho-nan, Korea, Dr. George van Biesbroeck; at Kiska and Adak, Lieut.-Cmdr. Clarence R. Reed and Mr. Clarence A. Shelton; while at the Japanese island of Rebun Jima there will be a Japanese astronomer selected by Prof. Hagihara, of the Tokyo Observatory. This marks a welcome move towards international co-operation in science between Japan and the United States. Measurements of the times of contact will be made by photographing the eclipse on $35-\mathrm{mm}$. sound motion pictures which will record the ticks of a chronometer on the sound track. The chronometers will be checked and rated from radio time-signals. The techniques which make these observations practicable have been developed to a high degree of efficiency in the last twelve years.

\section{Journal of the Institute of Navigation}

THE recently founded Institute of Navigation, the headquarters of which for the present are at the Royal Geographical Society, Kensington Gore, London, S.W.7, has issued the first number of its quarterly Journal (London: J. Murray. 25s. per annum). The object of the Institute is to unite those interested in the science and art of navigation, both by sea and in the air. Fellows are those who are either professional navigators or who have made outstanding contributions to the science of navigation; members are those who are generally interested. The Astronomer Royal is president of the Institute, and he has contributed to the new Journal an introductory address on the development of navigation. Other articles are on radio aids to navigation, consol, pressure pattern flying and many other topics. The new ocean weather service also finds a place: its ships, equipment and tasks are explained. The Journal promises to be a useful addition to the list of scientific periodicals.

\section{Plant Disease Charts}

Plant Protectron, Ltd., has recently issued two useful wall charts illustrating common and important crop diseases and pests. Both charts are beautifully produced in colour, depicting parts of the plants diseased and the insects where such are concerned. One is entitled "Some Crop Pests and Diseases" and illustrates and describes the following: tomato blight, celery leaf-spot, celery leaf miner, cabbage white caterpillar, black aphis, potato blight, carrot fly, turnip flea beetle, onion mildew, chocolate spot of broad bean, mole cricket, locust, pea and bean weevil, leatherjacket, wireworm, cutworm. The other, "Pests and Diseases of Apples", deals with brown rot, woolly aphis, sucker, apple and pear scab, winter and March moths, sawfly, capsid bug, codling moth, apple blossom weevil and apple mildew. Methods of prevention or protection are shortly described in each case. These wall charts will be a valuable visual aid for schools and agricultural colleges and institutes, which can obtain copies free of charge from Plant Protection, Ltd., Yalding, Kent.

\section{Biology of Lice}

A SECOND edition of the booklet entitled "Lice" by Dr. John Smart, published as Economic Series No. 2A by the British Museum (Natural History) has recently appeared (British Museum (Natural History), London, S.W.7, 1948. 9d.). It deals with the incidence, development and habits of lice affecting man and the best methods for controlling these pests. During the six years interval that has elapsed since the appearance of the first edition of this booklet, much new knowledge concerning lice has come to hand, especially relative to control measures acquired during the War. Information on these and other features are incorporated in the new edition.

\section{International Conference on the Physics of Metals}

THE Netherlands Physical Society is organising an international conference on the physics of metals, to be held at Amsterdam during July 12-18, after the Assembly of the International Union of Pure and Applied Physics. The provisional programme 